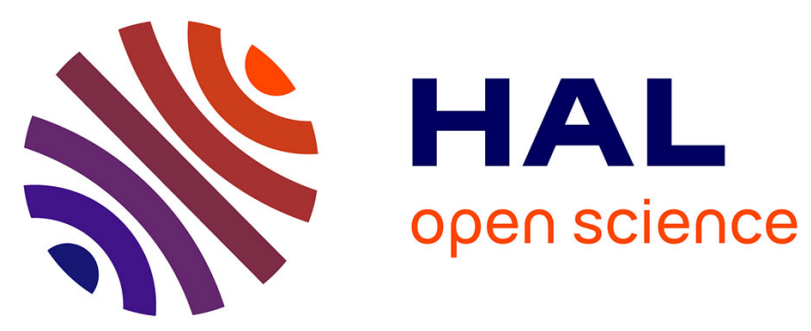

\title{
Determinants of reproductive performance among female Gray-cheeked mangabeys (Lophocebus albigena) in Kibale National Park, Uganda
}

Malgorzata E. Arlet, Lynne A. Isbell, Ants Kaasik, Freerk Molleman, Rebecca L. Chancellor, Colin A. Chapman, Raivo Mänd, James R. Carey

\section{To cite this version:}

Malgorzata E. Arlet, Lynne A. Isbell, Ants Kaasik, Freerk Molleman, Rebecca L. Chancellor, et al.. Determinants of reproductive performance among female Gray-cheeked mangabeys (Lophocebus albigena) in Kibale National Park, Uganda. International Journal of Primatology, 2015, 36 (1), pp.5573. 10.1007/s10764-014-9810-4. hal-01121734

\section{HAL Id: hal-01121734 \\ https://hal-univ-rennes1.archives-ouvertes.fr/hal-01121734}

Submitted on 2 Apr 2015

HAL is a multi-disciplinary open access archive for the deposit and dissemination of scientific research documents, whether they are published or not. The documents may come from teaching and research institutions in France or abroad, or from public or private research centers.
L'archive ouverte pluridisciplinaire HAL, est destinée au dépôt et à la diffusion de documents scientifiques de niveau recherche, publiés ou non, émanant des établissements d'enseignement et de recherche français ou étrangers, des laboratoires publics ou privés. 


\section{Determinants of reproductive performance among female gray- cheeked mangabeys (Lophocebus albigena) in Kibale National \\ Park, Uganda}

Małgorzata E. Arlet ${ }^{1,2^{*}}$, Lynne A. Isbell ${ }^{3}$, Ants Kaasik ${ }^{1}$, Freerk Molleman ${ }^{4}$, Rebecca L. Chancellor $^{5}$, Colin A. Chapman ${ }^{6}$, Raivo Mänd ${ }^{1}$, and James R. Carey ${ }^{7}$

${ }^{1}$ Department of Zoology, Institute of Ecology and Earth Sciences, University of Tartu, Tartu, Estonia

${ }^{2}$ Animal and Human Ethology Research Unit, University of Rennes 1, France

${ }^{3}$ Department of Anthropology and Animal Behavior Graduate Group, University of California, Davis, USA

${ }^{4}$ Ecosystems, Biodiversity and Evolution Research Unit, University of Rennes 1, Rennes, France

${ }^{5}$ Departments of Anthropology \& Sociology and Psychology, West Chester University, West Chester, USA

${ }^{6}$ Department of Anthropology and McGill School of Environment, McGill University, Montreal, Canada and Wildlife Conservation Society, Bronx, NY, USA

${ }^{7}$ Department of Entomology, University of California, Davis, USA

*To whom correspondence should be addressed: M.E. Arlet, maarlet@yahoo.com, phone: $+33643244050$ 
Arlet et al. p. 2

\begin{abstract}
Identifying the causes of differential reproductive success is key to understanding natural selection and the forces of selection operating on animals. Here we present results from a 9-yr (2004-2012) study of female reproductive performance in relation to mother's age and rank, presence of immigrant males, rainfall, and fig fruit abundance in four groups of gray-cheeked mangabeys (Lophocebus albigena) in Kibale National Park, Uganda. We found that females had a rank- and age-specific reproductive pattern, with high-ranking females maturing earlier, having their first births earlier, and exhibiting significantly slower reproductive aging than low-ranking females. We also found that both immigrant and resident males were associated with higher birth rates. Finally, we found that reproduction was aseasonal and not correlated with rainfall, but that births were positively correlated with the abundance of Ficus spp. fruits. Our results show broad similarities between arboreal, forest-dwelling gray-cheeked mangabeys and their more terrestrial, open habitat-dwelling papionin relatives in the importance of dominance rank in estrous cycle initiation, first reproduction, and reproductive aging.
\end{abstract}

Key words: primates, Old World monkeys, birth rate, reproductive maturation, female reproductive success 
Arlet et al. p. 3

\section{Introduction}

Differential reproductive success is a crucial component of natural selection and thus it is important to determine the social and ecological factors that influence lifetime reproductive success. For females, one of the key influences is differential access to food. Because female reproductive success is thought to be limited most by access to food (Trivers 1972), in group-living species competition over food may favor the expression of female dominance hierarchies (Wrangham 1980; van Schaik 1989; Isbell and Young 2002). In such species, higher-ranking females often have better access to food than lower-ranking females (Clutton-Brock et al. 1984; Harcourt 1987), and this is then expected to result in reproductive skew. Indeed, differences in reproductive parameters among females of disparate ranks have been reported in several primate species. For example, higher-ranking females give birth at earlier ages than lowerranking females among yellow baboons (Papio cynocephalus) (Altmann et al. 1988), mandrills (Mandrillus sphinx) (Setchell et al. 2002) and chimpanzees (Pan troglodytes) (Pusey et al. 1997). Higher-ranking females also have shorter interbirth intervals among olive baboons (P. anubis) (Barton and Whiten 1993), long-tailed macaques (Macaca fascicularis) (van Noordwijk and van Schaik 1987), Japanese macaques (M. fuscata) (Sugiyama and Ohsawa 1982), and chimpanzees (Pusey et al. 1997). Finally, higherranking females have higher infant survival among long-tailed macaques (van Noordwijk and van Schaik 1999) and chimpanzees (Pusey et al. 1997).

Reproductive success is also affected by lifespan, and lifespan may be shortened by predation. Predation may also interact with social rank differences in affecting reproductive success. For example, predation may exacerbate rank differences in reproductive success because lower-ranking females may be at greater risk of predation when they are excluded from central and safe feeding places (e.g., long-tailed macaques 
at Ketambe, Sumatra and chacma baboons (P. ursinus) in the Mkuzi Game Reserve, South Africa; van Noordwijk and van Schaik 1987; Ron et al. 1996).

Females that survive long enough to have multiple offspring gain experience with infant care that improves infant survival and thus reproductive success. For females that survive to older ages, it may be possible to observe changes in their reproductive strategies as they age. For instance, female reproductive strategies may change according to future reproductive and survival prospects (the terminal investment hypothesis: Clutton-Brock 1984). Many studies of mammals have shown, for example, that older females have heavier infants and higher offspring survival (e.g., red deer, Cervus elaphus: Clutton-Brock 1984; Nile lechwe, Kobus megaceros: Bercovitch et al. 2009; red squirrels, Sciurus vulgaris: Descamps et al. 2008; Hanuman langurs, Semnopithecus entellus: Dolhinow et al. 1979; Borries et al. 1991; rhesus macaques M. mulatta: Silk et al. 1993; Barbary macaques M. sylvanus: Paul et al. 1993). However, it is often unclear to what extent greater survival of infants of older mothers is a function of experience or physiology.

At advanced reproductive ages females may decline in their reproductive output (particularly in terms of birth rate) as a result of age-associated physiological deterioration (the senescence hypothesis: Weladji et al. 2002). A reduction in fecundity as females age has been observed, for example, in olive baboons (Strum and Western 1982), Japanese macaques (Koyama et al. 1975; but see Fedigan et al. 1986), rhesus macaques (Drickamer 1974; Hoffman et al. 2010), and Hanuman langurs (Dolhinow et al. 1979).

Reproductive output may also decline over time as a result of determinate reproduction. Females are born with a set number of oocytes, and as females cycle, the pool of available oocytes diminishes and females may enter a post-reproductive phase 
near the end of their life, i.e., menopause (Waser 1978; Bell and Koufopanou 1986; Atsalis and Videan 2009; Perheentupa and Huhtaniemi 2009; Pavelka and Fedigan 2012). The number of oocytes present at birth may depend on the nutrition of the mother before the daughter's birth, whereas the depletion rate of oocytes may depend on the rate of cycling and the frequency of pregnancies. The pregnancy rate may depend on nutrition and thus social rank, which may again be a function of the mother's rank, if female rank is "inherited". Therefore, it is difficult to predict the effect of rank on reproductive aging, but it is likely to play a role.

Female reproductive success may also be influenced by males. Males may have a positive effect on birth rates (per female) via infanticide (Borries 1997; Fedigan 2003; Fruteau et al. 2010) or by accidental deaths of infants during aggressive interactions among males (Arlet et al. 2014), both of which may reduce interbirth intervals while nonetheless reducing reproductive success. A positive effect on birth rate may be more likely when immigrant males join the groups because the risk of infanticide increases and there may be heightened aggression at those times. Immigrant males may also improve conception rates as a result of outbreeding. Indeed, female gray-cheeked mangabeys (Lophocebus albigena) preferentially mate with novel males (Arlet et al. 2007, 2008). In addition, greater numbers of resident males in groups may improve birth rates or reproductive success indirectly by providing stronger protection or defense of larger or better quality home ranges used by females (Robinson 1988).

In addition to social factors, female reproductive performance may be affected by fluctuations in environmental factors such as food abundance (Altmann et al. 1977; Dunbar 1980; Strum and Western 1982). In some African ecosystems, rainfall serves as a reliable proxy for plant productivity (McNaughton 1985), and in many primate species, births tend to be seasonal (Butynski 1988). Even aseasonally breeding primates, 
however, may be affected by variation in rainfall and thus food abundance. Among yellow baboons in Amboseli National Park, Kenya, for instance, shorter interbirth intervals are correlated with higher amounts of rain (Altmann et al. 1977).

Although the factors that affect female reproductive performance have been comparatively well studied in terrestrial baboons and macaques, investigations of reproductive performance in arboreal, forest-dwelling papionin primates are rare. To our knowledge, the only such species in which female reproductive performance has been investigated are long-tailed macaques (van Noordwijk and van Schaik 1999) and Assamese macaques (M. assamensis; Fürtbauer et al. 2010).

Gray-cheeked mangabeys are arboreal, forest-dwelling, African monkeys that are closely related to baboons (Harris and Disotell 1998; Burrell et al. 2009). Like baboons, they live in multi-male, multi-female groups, but group sizes are typically smaller than those of baboons (Waser 1977; Henzi and Barrett 2003). Also like baboons, females usually remain in their natal groups throughout life and have stable, linear dominance hierarchies (Chancellor and Isbell 2009a, b), whereas males disperse from their natal groups and compete with other males for rank as they attempt to join other groups around sexual maturity (Olupot and Waser 2001). Mangabeys are predominantly frugivorous (Waser 1977; Chancellor and Isbell 2009a), and appear to be aseasonal breeders (Wallis 1983; Olupot and Waser 2013).

This study explores to what extent sociality, ecology, and phylogeny contribute to the reproductive performance of female gray-cheeked mangabeys, information that is useful for assessing the generality of baboon and macaque derived patterns to other papionin genera. Based on theoretical expectations and empirical findings of other papionins, we predict the following: 1) high-ranking female gray-cheeked mangabeys will have higher reproductive output than lower-ranking females via earlier maturation (as measured by 
estrous cycle initiation), younger ages at first birth, and higher birth rates; 2) fertility will decrease with age independent of rank; 3) greater numbers of immigrant and resident adult males will lead to increased birth rates, and; 4) greater rainfall and higher abundance of Ficus spp. fruits will be positively correlated with conception and therefore the number of births 6 months later.

\section{Methods}

Study area and subjects

We conducted the study in Kibale National Park, Uganda $\left(0^{\circ} 13^{\prime}-0^{\circ} 41^{\prime} \mathrm{N}\right.$ and $30^{\circ} 19^{\prime}$ - $\left.30^{\circ} 32^{\prime} \mathrm{E}\right)$, near the Makerere University Biological Field Station. Kibale $\left(795 \mathrm{~km}^{2}\right)$ is a moist, evergreen, medium altitude forest with a mosaic of swamp, grassland, thicket, and mature and colonizing forest (Chapman et al. 2010). The gray-cheeked mangabey population in Kibale has been studied intermittently since the 1970s. Despite a typically bimodal pattern of yearly precipitation, with more rain falling in March-April and September-November (Struhsaker 1975; Isbell 2012; Valtonen et al. 2013), there appears to be no detectable birth seasonality in this population (Wallis 1983; Olupot and Waser 2013). We report data from four habituated groups (BT1, CC, MK and LC1) studied from 2004-2012, which ranged in size from 10 to 23 individuals (Table 1).

Table 1. Ranges and means (in brackets) of group compositions in gray-cheeked mangabey population in Kibale National Park, Uganda between 2003 and 2012 .

\section{BT1}

\section{CC}

LC1

MK

\begin{tabular}{lcccc}
\hline Group size & $10-12(14.3)$ & $15-22(16.9)$ & $16-23(19.6)$ & $10-17(12.9)$ \\
Adult females & $4-7(5.9)$ & $4-7(5.4)$ & $6-8(7.0)$ & $3-5(4.5)$ \\
Adult males & $2-7(3.6)$ & $1-4(2.4)$ & $3-8(5.1)$ & $1-4(1.9)$ \\
Subadult (both sexes) & $0-3(1.3)$ & $0-2(0.9)$ & $0-2(1.4)$ & $0-2(1.4)$ \\
Juveniles (both sexes) & $0-4(2.5)$ & $0-4(2.6)$ & $0-7(2.3)$ & $0-4(2.0)$
\end{tabular}


Between August 2004 and July 2006, each group was observed for an average of three days per month (Chancellor and Isbell 2009a). Between August 2006 and December 2012, each group was followed for up to six consecutive days on a five-week rotation schedule (Arlet et al. 2009).

We began identifying females in January 2004. Females were initially identified as individuals using natural markings such as relative body size, nipple color and size, and tail characteristics (scars, shape, and thickness of hair). The number of adult females ranged from 21 (2007-2008) to $26(2009,2011-2012)$, with a mean of 22.6 females per year. Two adult females immigrated into our groups, one transferred to a non-study group, and nine disappeared. Analyses are drawn from a total of 38 adult females over the nine-year period.

When a new infant was first seen in a group, we counted it as a birth. Since we did not follow the groups continuously, pregnancy losses, stillbirths, or very early mortality could have occurred without our knowledge. We defined infants as animals less than 18 months old (Waser 1974). During this study, 76 infants were born in the four study groups, including 12 infants to primiparous mothers. Infants were considered to have died when they were no longer seen, since infants are unlikely to survive by themselves.

Age and rank of adult females

We knew approximate birth dates (within 6 weeks) for all 12 adult females who matured and gave birth for the first time during this study. Females were classified as mature when they exhibited a sexual swelling for the first time. These were all 6-8 years old by the end of the study. We could also estimate birth months for two females who were still dependent on their mothers when our study began. We categorized the ages of the other older 24 females into four-year intervals (based on Strum and Western 1982, for 
baboons, and modified here for mangabeys) that described the reproductive status of each female: young multiparous (8-12 yrs), middle-aged multiparous (12-16 yrs), old multiparous (16-20 yrs) and very old multiparous (over $20 \mathrm{yrs}$ ). We estimated age classes based on relative size, skin condition of perineal sexual swelling, nipple length, and general marks of aging, such as wrinkled skin on the face and the neck, saggy skin around the face, and thinning hair.

We calculated female ranks as in Arlet et al. (2014). Briefly, we used focal and ad libitum sampling to record agonistic interactions. We recorded 136-318 dyadic agonistic interactions per group, including nonphysical threats (e.g., facial displays), approachavoids (i.e., moving away from another who is approaching), supplants (i.e., taking the place of another), physical contact (e.g., biting, tail-pulling, and pushing), and chases (i.e., aggressively pursuing another) (see also Chancellor and Isbell 2009a, b). We constructed dominance matrices for each group, with rank order determined by minimizing the number of reversals against the hierarchy (i.e., interactions below the diagonal). 
Table 2. Individual female gray-cheeked mangabeys according to group and rank, along with their putative or known ages (at first year of study) and maternal relationships (mother given in parentheses).

\begin{tabular}{|c|c|c|c|c|c|c|c|c|c|c|c|c|}
\hline \multirow{10}{*}{$\begin{array}{c}\text { BT1 } \\
\text { group }\end{array}$} & Year & KS & KG & KB & KK & MK & WI(KG) & GZ(KS) & $\mathrm{DO}(\mathrm{KS})$ & HK(KB) & HM(KB) & $\operatorname{PO}(K K)$ \\
\hline & 2004 & 1 & 2 & 3 & 4 & 5 & & & & & & \\
\hline & 2005 & 1 & 2 & 3 & 4 & 5 & & & & & & \\
\hline & 2006 & 1 & 3 & 4 & 5 & 6 & & & 2 & & & \\
\hline & 2007 & 1 & 3 & 4 & 5 & 6 & & & 2 & & & \\
\hline & 2008 & 1 & 3 & 4 & 5 & 6 & & & 2 & & & \\
\hline & 2009 & 1 & 4 & 6 & 7 & & 5 & 2 & 3 & & & \\
\hline & 2010 & 1 & 4 & 6 & & & 5 & 2 & 3 & & 7 & \\
\hline & 2011 & 1 & & 7 & & & 4 & 2 & 3 & 5 & 6 & \\
\hline & 2012 & 1 & & 7 & & & 4 & 2 & 3 & 5 & 6 & 8 \\
\hline
\end{tabular}

\begin{tabular}{|c|c|c|c|c|c|c|c|c|c|c|}
\hline \multirow{10}{*}{$\begin{array}{c}\text { CC } \\
\text { group }\end{array}$} & Year & MY & BO & $\mathbf{K U}$ & KE & MZ & IR(MZ) & $\mathbf{G I}(\mathbf{K U})$ & TB & $\mathrm{KN}(\mathrm{KU})$ \\
\hline & 2004 & 1 & 2 & 3 & 4 & 5 & & & & \\
\hline & 2005 & 1 & 2 & 3 & 4 & 5 & & & & \\
\hline & 2006 & 1 & 2 & 3 & 4 & 5 & & & & \\
\hline & 2007 & & 1 & 2 & 3 & 4 & & & & \\
\hline & 2008 & & 1 & 2 & 3 & 4 & 5 & & & \\
\hline & 2009 & & 1 & 2 & 4 & 6 & 5 & 3 & 7 & \\
\hline & 2010 & & 1 & 3 & 4 & 6 & 5 & 2 & 7 & \\
\hline & 2011 & & 1 & 3 & 4 & 6 & 5 & 2 & 7 & \\
\hline & 2012 & & 1 & 4 & 5 & & & 2 & 6 & 3 \\
\hline
\end{tabular}




\begin{tabular}{|c|c|c|c|c|c|c|c|c|c|c|c|}
\hline \multirow{10}{*}{$\begin{array}{c}\text { LC1 } \\
\text { group }\end{array}$} & Year & NG & MB & NT & NS & $\mathbf{K I}$ & NM & ZI & SK & KO & $\mathbf{H J}(\mathrm{KI}$ \\
\hline & 2004 & 1 & 2 & 3 & 4 & 5 & 6 & & & 7 & \\
\hline & 2005 & 1 & 2 & 3 & 4 & 5 & 6 & & & 7 & \\
\hline & 2006 & 1 & 2 & 3 & 4 & 5 & 6 & & & 7 & \\
\hline & 2007 & & 1 & 2 & 3 & 4 & 5 & & & 6 & \\
\hline & 2008 & & 1 & 2 & 3 & 4 & 5 & 6 & & 7 & \\
\hline & 2009 & & & 1 & 2 & 3 & 5 & 4 & 6 & 7 & \\
\hline & 2010 & & & 1 & 2 & 3 & 5 & 4 & 6 & 7 & \\
\hline & 2011 & & & 1 & 2 & 3 & 6 & 5 & 7 & 8 & 4 \\
\hline & 2012 & & & 1 & 2 & 4 & 6 & 5 & 7 & 8 & 3 \\
\hline
\end{tabular}

\begin{tabular}{cccccccccc} 
MK & Year & KT & KD & NK & NB & IJ & RO(KT) & WO(IJ) & LD(KD) \\
\cline { 2 - 10 } group & 2004 & 1 & 2 & 3 & 4 & 5 & & & \\
& 2005 & 1 & 2 & 3 & 4 & 5 & & & \\
& 2006 & 1 & 2 & 3 & 4 & 5 & & & \\
& 2007 & 1 & 2 & 3 & 4 & 5 & & & \\
& 2008 & 1 & 2 & & 3 & & & & \\
& 2009 & 1 & 3 & & 4 & & 2 & 5 &
\end{tabular}


Arlet et al. p. 12 
All groups had dominance hierarchies that rarely changed, the exceptions occurring when females rose in the dominance hierarchy as a consequence of deaths of highranking mothers or their daughters (see also Chancellor and Isbell 2009a, b). Between 2004 and 2012, 6 females changed from low- to high-ranking or vice versa, and they were classified in each year separately.

Identification of estrous cycles based on sexual swellings

Female gray-cheeked mangabeys exhibit sexual swellings that cover a relatively small area ventral to the base of the tail (Rowell and Chalmers 1970; Chalmers and Rowell 1971; Danjou 1972; Wallis 1983). The swelling increases in size and color gradually, deepening to pink at maximum swelling. As estrus passes, the swelling deflates and turns dark purple (Deputte, 1991; Wallis, 1983). Sexual swellings last on average 17-38 days in three phases: quiescence to peak swelling lasting 4-14 days, peak swelling lasting 2-4 days, and deflation lasting 7-14 days (Danjou, 1972; Deputte, 1991; Rowell and Chalmers, 1970; Wallis, 1983).

During observations, we noted the condition of each female as either having no sexual swelling (not cycling) or having a visible sexual swelling, with different degrees of swelling also noted, i.e., inflating, peak, or deflating (cycling). Twelve females began cycling during the study. In captivity, mangabey estrous cycles average 31.2 days, with a range of 29 to 38 days (Deputte 1991). With our observation schedule, we were able to note the reproductive state of each female every 28-35 days. Since we did not follow each individual every day, we could not obtain precise information about variation in the length of estrous cycles and dealt with this issue statistically (see "data analysis" section below). 
Presence of immigrant males

After August 2006, we noted the presence of immigrant males with the focal group. Immigrant males were adult males who joined any of the groups during the year. All immigrants except one entered the groups as low-ranking males. However, one of the immigrants rose from low-ranking to high-ranking rapidly after the dominant male left the group. Once the males were in a group for 6 months, we considered them resident males because by this time their glucocorticoid profiles became indistinguishable from those of resident males (Arlet et al. 2009), suggesting that they had become integrated into their groups. As males become integrated, they engage in fewer aggressive interactions within groups and infant mortality decreases (Arlet et al. 2014). Immigrant males were present with the groups for $27 \%$ of our observation time.

Rainfall and phenological data

Data on rainfall were collected daily at the research station and served as a general indication of food abundance. As the majority of the gray-cheeked mangabey diet consists of fruit (Waser 1977; Olupot 1998; Chancellor and Isbell 2009a) and the most highly preferred fruits are figs (Ficus spp.) (Waser 1974; Janmaat et al. 2006; Janmaat and Chancellor 2010), we also focused on the abundance of ripe and unripe figs (both of which are eaten by gray-cheeked mangabeys) as recorded between 2003-2012. We monitored 300 Ficus spp. trees of 33 fig species along phenology transects (Chapman et al. 2005). Each month the crowns of these species were visually examined and the presence of unripe and ripe fruits was noted on a scale from $0-4$ with 0 being absent and 4 being maximally abundant.

Statistical analyses 
We performed all analyses using the statistical software R (R Development Core Team 2011). We used generalized linear mixed models (GLMM), using the lme4 package (Bates et al. 2011) to test 1) the effects of adult female rank and age as predictor variables on the timing and frequency of estrous cycles, and 2) adult female rank and age, total number of males present, rainfall, and abundance of ripe and unripe Ficus spp. fruits (around the time of conception) on birth rates.

Given that latencies between observation days per female were irregular, to estimate the number of estrous cycles we implemented a Poisson rate regression model with group as a random effect and the logarithm of observation time as an offset. Using the logarithm of the observation time as model offset is a device for correcting the differences in the observation period for Poisson rate models (Faraway 2005). We used 31.2 days as the length of an average cycle in our analyses, and we counted the occurrence of maximum sexual swellings directly ('peaks') or indirectly (by 'inflating' or 'deflating' stages). This gave us the number of estrous cycles without pinpointing the dates of each peak phase, as well as the number of days for which we had enough observations to detect full cycles. We also counted the number of infants that a female had during our observation period and excluded 175 days for gestation and a minimum of 300 days for lactation periods (if the infant survived; Deputte 1991).

We analyzed the effects of dominance rank on estrous cycles in three ways by fitting three separate GLMMs. As in Arlet et al. (2014), we labeled those 1-2 females per group who won 54-92\% of the encounters in their group during a given year "high-ranking" and all other females "low-ranking" because they lost those encounters. First, we first compared high- vs. low-ranking females. As there are multiple ways to quantify relative dominance ranks, to test for consistency with this dichotomous rank categorization, we assigned ranks to females on an inverse scale where the highest ranking individual is 1 , 
the second 0.5 , the 3rd 0.33, etc., and we also checked an even distribution where the highest rank is 1 , the lowest is 0 , and all other individuals are placed at regular intervals between them (Arlet et al. 2014).

For the GLMM involving the effects of female rank and age, total number of immigrant and resident males present, rainfall, and abundance of ripe and unripe Ficus spp. fruits on birth rates we implemented a logistic regression with individual female and the time period as random factors to account for possible correlation for observations for the same female and for the same 6-month time period, respectively. Correlation of successive 6-month time periods (for a particular female) was taken into account using a predictor in the model that described the proportion of time that a female was unavailable to give birth in a period (due to giving birth during one of the earlier periods). Births were aggregated into 6-month periods (i.e., for each female for a particular period, 1 indicated that the female gave birth, and 0 that she did not). This aggregation was necessary as sometimes the exact birth date was not known and several of the predictors were not measured frequently enough to produce a reliable estimate for a shorter time interval, the exceptions being rainfall data which were recorded daily and Ficus spp. data which were recorded each month. All predictors were offset by 6 months to coincide with conceptions associated with observed births (mean gestation length: 175 days, Deputte 1991). Weighted means were calculated for predictors where appropriate. There were no significant differences among groups in this analysis, the SD of the random effect of group being zero. We used AIC to select the best model for predicting birth rates. T-tests were used to compare difference between high- and low-ranking females in reproductive parameters. A Kruskal-Wallis test was used to test the effect of the survival of previous infants in their first year on interbirth interval.

\section{Results}


Population patterns of reproductive performance

We confirmed that gray-cheeked mangabeys are aseasonal breeders as births occurred in every month of the year (Figure 1). On average, females gave birth to their first infants after 11.5 cycles. The overall birth rate was 0.36 births per female per year (i.e., approximately 1 birth every 3 years), but there was considerable variability as $25 \%$ of the population had a birth rate estimate lower than 0.22 and another $25 \%$ had higher than 0.44. Females losing their infants within the infant's first year of life resumed cycling and had shorter interbirth intervals than females whose infants survived (mean: 16.7 and 30.3 months, respectively; Kruskal-Wallis rank sum test, $\left.\chi^{2}=20.08, \mathrm{df}=1, \mathrm{p}<0.001\right)$.

Figure 1. Distribution of births per month in gray-cheeked mangabeys from 2004-2012 in Kibale National Park, Uganda.

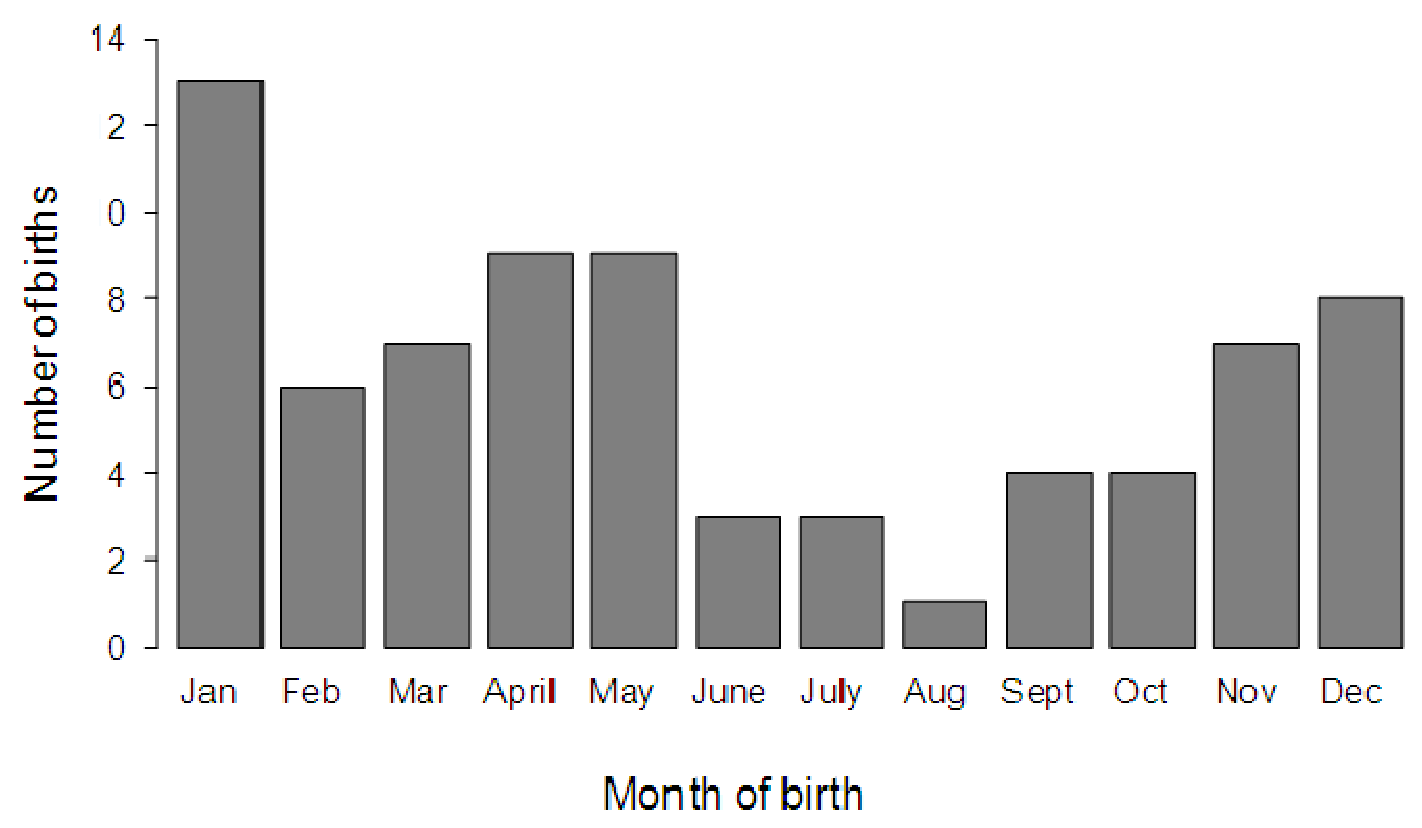

Female dominance rank and age relative to timing of and frequency of estrous cycles High-ranking females matured earlier than low-ranking females. Among those that matured during the study, high-ranking females had their first estrous cycle two months 
earlier, on average, than low-ranking females (HR range $=5.0-5.25 \mathrm{yrs}$, mean $\pm \mathrm{SD}=$ $5.1 \pm 0.1, \mathrm{~N}=4 ;$ LR range $=5.1-6.2$ yrs, mean $\pm \mathrm{SD}=5.4 \pm 0.4, \mathrm{~N}=9$; exact birth dates were not known for two females; $\mathrm{t}$-test, $\mathrm{t}=-1.94, \mathrm{df}=10.11, \mathrm{p}=0.041,1$-tailed). Reproductive maturation relative to mother's rank did not change substantially when we modeled rank using the alternatives of inverse and even rank distributions.

Among these maturing females, high-ranking individuals had a mean of 13 estrous cycles before the birth of their first infant $(\mathrm{N}=5, \mathrm{SD}=2.4)$, while low-ranking females had a mean of 10 estrous cycles before their first birth $(\mathrm{N}=7, \mathrm{SD}=3.3$; t-test, $\mathrm{t}=1.76$, df $=9, \mathrm{p}=0.112,1$-tailed). Nonetheless, high-ranking females gave birth to their first infants significantly earlier (a year earlier on average) than low-ranking females (6.8 yr, $\mathrm{N}=5$ high-ranking females vs. $7.8 \mathrm{yr}, \mathrm{N}=7$ low-ranking females; $\mathrm{t}$-test, $\mathrm{t}=3.21, \mathrm{df}=10$, $\mathrm{p}=0.009$ ). From these data, and taking into account the gestation period of 175 days, we estimated the length of estrous cycles. For high-ranking females, average estrous cycle length was 31.2 days, and for low-ranking females, 33.6 days.

Cycle frequency decreased with age. At mean relative rank, older females had fewer estrous cycles $(\mathrm{z}=-8.08, \mathrm{p}<0.001$, Table 3$)$. We observed cessation of reproductive activity in two old females (> $20 \mathrm{yrs}$ ). Female KB (low-ranking, BT1 group) gave birth at the beginning of 2009 and afterward did not resume cycling. In 2004, when Chancellor started following LC1 group, female NB (high-ranking) was not cycling. NB kept her position as alpha female until she disappeared at the end of 2007, and throughout this time she did not cycle.

Interactions between rank and age on estrous cycles 
Modeling all adult females in the population suggested that for the average age of $12.5 \mathrm{yr}$, females of higher relative rank had more estrous cycles $(\mathrm{z}=-4.40, \mathrm{p}<0.001$;

Table 3, Figure 2). At mean relative rank, older females had fewer estrous cycles; $z=-$ 8.08, $\mathrm{p}<0.001$; Table 3, Figure 2). However, there was an interaction between rank and age, whereby the number of estrous cycles did not decrease as rapidly for high-ranking females $(z=-1.96, p=0.049$; Table 3, Figure 2).

Table 3. Parameter estimates for the quasi-Poisson model of female cycle frequency of gray-cheeked mangabeys in Kibale National Park for the years 2004-2012. Logarithm of the number of days observed was used as an offset.

\begin{tabular}{lrrr} 
& \multicolumn{2}{c}{ Estimate SE $\quad \mathrm{p}$} \\
Intercept & -4.307 & $0.063<0.001$ \\
Relative rank $-0.6^{\mathrm{a}}$ & -0.755 & $0.171<0.001$ \\
Age $-12.5^{\mathrm{b}}$ & -0.084 & $0.010<0.001$ \\
(Relative rank - 0.6) x (Age - 12.5) & -0.070 & 0.035 & 0.049 \\
SD (Group) & 0.084 & &
\end{tabular}

${ }^{\mathrm{a}}$ The rank of the individual minus the average rank of all females.

${ }^{\mathrm{b}}$ The age of the individual minus the average age of all females. 
Figure 2. Changes in cycle frequency and birth rate with age in high-vs. low-ranking female gray-cheeked mangabeys in Kibale National Park, Uganda for the years 20042012 (model result, see text). Gestation and lactation periods have been omitted and thus a year might correspond to a longer period in time. This figure is based on local polynomial regression fitting. Due to the small sample size of the data, the actual proportions are variable and as such are not useful for plotting. This figure is presented for illustrative purposes as the actual effects are analyzed using statistical models. HR= high-ranking females; $L R=$ low-ranking females .

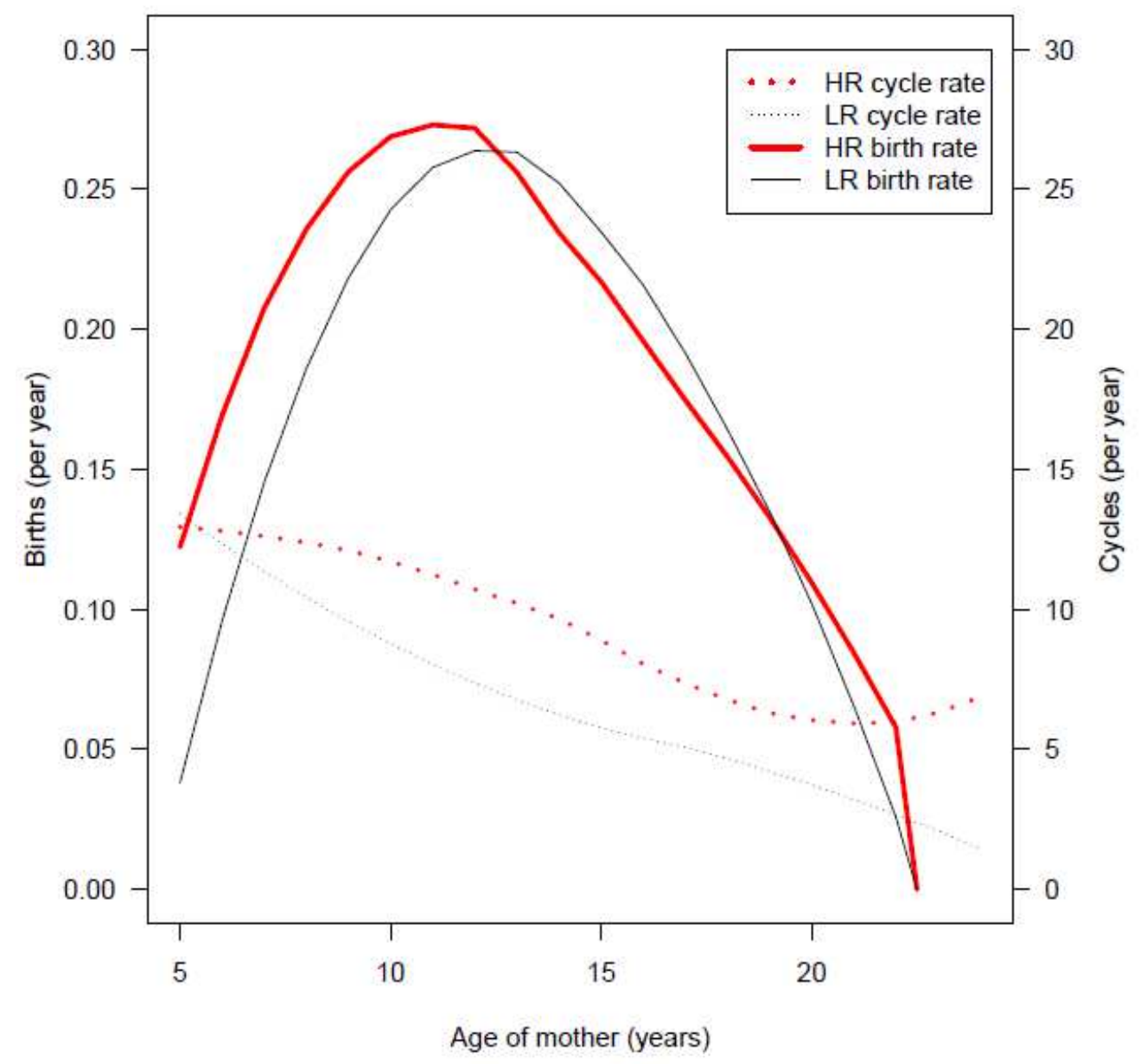

Variables predicting birth rates

The model with the best fit included age, rank, the interaction between age and rank, presence of immigrant and resident males, and abundance of fig fruits, but not rainfall.

We found that as adult females in the population aged, their birth rates declined significantly $(\mathrm{z}=-2.93, \mathrm{p}=0.003$, Table 4; Figure 2). High-ranking females had on 
average higher birth rates than low-ranking females during the younger ages, but by the average age of 12.5 years this difference no longer existed (Figure 2).

[Insert Table 4 here]

The numbers of immigrant and resident adult males in the group at the time of conception were both positively associated with birth rate $(\mathrm{z}=2.88, \mathrm{p}=0.004$ and $\mathrm{z}=2.31, \mathrm{p}=$ 0.021, respectively; Table 4).

Ficus spp. fruit availability during conception was significantly positively correlated with frequency of births $(z=2.51, p=0.012$; Table 4$)$. However, there appears to be no relationship between rainfall and conceptions as rainfall fell out of the final model.

\section{Discussion}

Our results showed that rank, age, greater numbers of immigrant males, and greater numbers of resident adult males are all important influences on female reproductive performance in gray-cheeked mangabeys. We also found an association between Ficus spp. fruit abundance around the time of conception and thus the temporal distribution of births. Gray-cheeked mangabeys' maturation and reproductive aging appear to be similar to baboons, mandrills and macaques, and other papionins that are typically more terrestrial, suggesting that broad habitat preferences exert little influence on females' reproductive performance.

Female gray-cheeked mangabeys live in female-resident groups with linear dominance hierarchies (Chancellor and Isbell 2009a, b). Regardless of their ranks, all females are able to breed, albeit with different success. Although the reproductive skew of high- and low-ranking female gray-cheeked mangabeys is not as great as in some mammalian species where low-ranking females do not reproduce at all (Creel and Creel 
2002), being a low-ranking female does appear to be disadvantageous in gray-cheeked mangabey societies, at least in early adulthood.

High-ranking female gray-cheeked mangabeys begin developing sexual swellings indicating the start of sexual cycling at younger ages and they begin reproducing a year earlier than low-ranking females. They also have more cycles before they conceive. This latter finding might suggest that initial cycles are anovulatory. Earlier age at first reproduction is correlated with high rank, as has been observed in other primates, e.g., rhesus macaques and mandrills (Bercovitch and Berard 1993; Setchell et al. 2002). Highranking females appear to have shorter and more frequent cycles than low-ranking females, and this continues throughout their lives. Reproductive aging also appears to be slower for high-ranking females than for low-ranking females as suggested by a slower decline in estrous cycle frequency over time. The rank effect is most obvious for younger females. After age 12.5, high-and low-ranking females converge in having similar birth rates. A slowing of birth rates and cycle frequency with age has also been documented in olive baboons (Strum and Western 1982), rhesus macaques (Gagliardi et al. 2007; Hoffman et al. 2010), mountain gorillas (Gorilla beringei, Robbins et al. 2006), and Barbary macaques (Paul et al. 1993).

Our study also reveals a decline in reproductive rate at advanced ages, especially in cycling rate, but also in birth rate, and in some cases, reproductive cessation (postreproductive lifespan/menopause). Reproductive cessation in our study species was previously reported by Waser (1978). Reproductive aging of females is a conspicuous phenomenon in humans, but is not ubiquitous among other animals (Jones et al. 2014; Roach and Carey 2014). In primates, age effects on reproductive rate tend to be small, and reproductive cessation is absent or confined to the oldest (Johnson and Kapsalis 1995; Wasser et al. 1998; Pavelka and Fedigan 1999; Robbins et al. 2006; Johnson and 
Kapsalis 2008; Videan et al. 2008; Herndon et al. 2012; Tian et al. 2013). Any reduced frequencies of cycling and birthing may be confounded by longer lactation periods, partly because older female gray-cheeked mangabeys have higher infant survival, and females tend not to conceive during this period (Arlet et al. 2014). However, we excluded these periods from our analyses of cycle and birth rates. As reproductive aging is often interpreted as follicular depletion (Atsalis and Videan 2009; Hawkes and Smith 2010), higher-ranking females may start with more oocytes, or deplete follicles at a slower rate. Higher-ranking females may endow their daughters with higher reproductive potential, thus preparing them for inheriting their high rank, which we show to be associated with long reproductive life. This may in turn explain why higher-ranking females tend to have relatively more female offspring (Arlet et al. 2014): daughters are able to reliably benefit from their mother's high rank. Slower follicular depletion may potentially be explained by higher-ranking females spending a larger proportion of their life pregnant, even though follicular depletion will be faster at other times given their higher cycling rate.

Estrous cycle lengths in our population are within the range of those found in a captive population of gray-cheeked mangabeys. Deputte (1991) pointed out two patterns in the captive population: a short 29.9-day cycle and a long 37.7-day cycle. The average cycle length of high-ranking females in our study is longer than the 'short cycle' of captive females (31.2 days) whereas the cycle length of low-ranking females is shorter than the 'long cycle' of captive females (33.6 days). Unfortunately, no information is available about the dominance ranks of the nine studied females from Deputte's study.

Birth rates can increase as a result of lower infant survival or greater access to food, both of which can shorten interbirth intervals. In gray-cheeked mangabeys, the death of an infant shortens the interbirth interval by approximately one year. Shortened interbirth intervals after the deaths of infants, through infanticide or other causes, have also been 
found in captive gray-cheeked mangabeys (Deputte 1991) as well as in several other primate species, including Sanje mangabeys (Cercocebus sanjei) (Fernandez et al. 2014) and captive golden-bellied mangabeys (C. agilis) (Walker et al. 2004), Hanuman langurs (Borries and Koening 2000), chacma baboons (Cheney et al. 2004), and blue monkeys (Cercopithecus mitis) (Cords and Chowdhury 2010; Cords and Fuller 2010). This suggests that infanticide could be an effective reproductive strategy for the male graycheeked mangabeys of Kibale and may in part explain aggression toward infants by immigrant males (Arlet et al. 2008). However, there is no direct evidence of infanticide in this species despite many years of observation. In a previous study, we showed that immigrant male presence in groups was associated with an increase in infant mortality but not through confirmed infanticide: $86 \%$ of the infants that died after falling from trees during fights between adult males fell when immigrant males were present in the group, and $46 \%$ of the infants that disappeared healthy did so while immigrant males were clearly present (compared to $23 \%$ when immigrant males were clearly absent) (Arlet et al. 2014).

The positive association between immigrant males and birth rate found in this study may exist because the greater infant mortality associated with immigrant males shortens interbirth intervals. It is also possible that the positive association between immigrant males and birth rate exists because females preferentially mate with novel males (Arlet et al. 2007). Similarly, we found that birth rates were positively associated with greater numbers of resident adult males. It has been suggested that having more adult males within the group helps females maintain or even increase their food supply when males are involved in intergroup competition (Robinson 1988). There is some support for this in gray-cheeked mangabeys. Male gray-cheeked mangabeys have a characteristic loud call, the whoop-gobble that function in part to mediate intergroup spacing because groups 
move away from the direction of whoop-gobbles from other groups (Waser 1975; Olupot and Waser 2013). High-ranking males give the most whoop-gobbles but this is dependent on the number of males in groups; high-ranking males in groups with more males give more whoop-gobbles than high-ranking males in groups with fewer males (Arlet et al. 2008). Moreover, males are aggressive toward other groups more often than are females and they are more likely to be aggressive toward other groups during periods of low food abundance and with patchily distributed foods (Brown 2013). Thus, having more males in gray-cheeked mangabey groups may be advantageous to females because more males may be more effective in protecting food resources for females. Since food is crucial to female reproductive success and greater access to foods can increase birth rates, the relationship between resident males and higher birth rates may be causal if indeed males protect the food supply for females in their groups.

The link between female reproductive success and nutrition is apparent in the close association between birth rate and monthly abundance of figs at conception, an important food resource for mangabeys in Kibale. Figs are also important in the timing of female chimpanzee reproduction at the same site (Sherry 2002). Indeed, food appears to be an important limiting factor for female reproductive success in this mangabey population, as may also be the case for many other primate species (Dittus 1979; Isbell 1991; Emery Thompson and Wrangham 2008; McCabe and Emery Thompson 2013). Our data confirm that gray-cheeked mangabeys respond to food availability in an opportunistic fashion, with females being more likely to conceive when figs are abundant. Such a capital breeding strategy might be expected for a frugivore in Kibale since fruiting phenology generally does not follow a clear seasonal pattern (Chapman et al. 1999, 2005).

In conclusion, our study provides evidence for fitness benefits of high dominance rank independent of age in female gray-cheeked mangabeys, reproductive aging in the 
wild, and slower reproductive aging in higher-ranking females compared to lowerranking females. These findings are qualitatively similar to other papionins and it appears that broad substrate and habitat differences, i.e., arboreal life in a forest vs. terrestrial life in more open habitats, are less important than phylogeny in determining reproductive performance. We also provide evidence suggesting a benefit to female reproductive output in having multiple males in their groups. Finally, we confirm that reproduction in this population of gray-cheeked mangabeys is aseasonal, perhaps a reflection of unpredictable fig fruiting patterns in Kibale.

\section{Acknowledgments}

We thank the Uganda Wildlife Authority, Uganda National Council for Science and Technology, and personnel at the Makerere University Biological Field Station in Kanyawara for permission to work in Kibale National Park. We thank all the field assistants that worked with us during these years: Kaseregenyu Richard, Katusabe Swaibu, Irumba Peter, Sabiti Richard, Akora Charles, Koojo John for their invaluable assistance in the field. Thanks also to Linda-Liisa Veromann for help in entering behavioral data. This research was supported by funds from the Leakey Foundation and the Department of Anthropology, University of California at Davis to RLC, NIH/NIA grants PO1 A6022500 and PO1 A608761 to JRC, "Mobilitas" postdoctoral grant MJD56 to MEA, and NSERC grants to CAC. The Estonian Ministry of Education and Science and the European Regional Development Fund supported RM and FM (targeted financing projects numbers 0180004s09 and 0180122s08, ESF 9215,7406, 7699, 7522, 8413 and GD6019; Center of Excellence FIBIR). This study complies with the current laws of Uganda. Finally, we appreciate the comments and suggestions by the editor and two anonymous reviewers to improve the manuscript. 


\section{Ethical standards}

The study complies with the current laws of Uganda.

\section{References}

Altmann J, Altmann SA, Hausfater G, McCuskey SA (1977) Life history of yellow baboons: physical development, reproductive parameters and infant mortality. Primates 18: 315-330

Altmann J, Hausfater G, Altmann SA (1988) Determinants of reproductive success in savannah baboons Papio cynocephalus. In Clutton-Brock TH (ed) Reproductive success, University of Chicago Press, Chicago, pp 403-418

Arlet ME, Molleman F, Chapman CA (2007) Indications for female mate choice in greycheeked mangabeys Lophocebus albigena johnstoni in Kibale National Park, Uganda. Acta Ethol 10: 89-95

Arlet ME, Molleman F, Chapman CA (2008) Mating tactics in male grey-cheeked mangabeys (Lophocebus albigena). Ethology 114: 841-852

Arlet ME, Grote MN, Isbell LA, Molleman F, Carey JR (2009) Reproductive tactics influence cortisol levels in individual male gray-cheeked mangabeys (Lophocebus albigena). Horm Behav 55: 210-216

Arlet ME, Isbell LA, Molleman F, Kaasik A, Chancellor RL, Chapman CA, Mänd R, Carey JR (2014) Maternal investment and infant survival in gray-cheeked mangabeys (Lophocebus albigena). Int J Primatol 35: 476-490

Atsalis S, Videan E (2009) Reproductive aging in captive and wild common chimpanzees: factors influencing the rate of follicular depletion. Am J Primatol 71: $271-282$ 
Arlet et al. p. 28

Barton RA, Whiten A (1993) Feeding competition among female olive baboons, Papio anubis. Anim Behav 46: 777-789

Bates D, Maechler M, Bolker B (2011) lme4: Linear mixed-effects models using S4 classes. R package version 0.999375-41/r1341. http://R-Forge.Rproject.org/projects/lme4/

Bell G, Koufopanou V (1986) The cost of reproduction. In Dawkins R, Ridley M (eds) Oxford surveys in evolutionary biology, vol. 3, Oxford University Press, Oxford, pp 83-131

Bercovitch FB, Berard JD (1993) Life history costs and consequences of rapid reproductive maturation in female rhesus macaques. Behav Ecol Sociobiol 32: 103109

Bercovitch FB, Loomis CP, Rieches RG (2009) Age-specific changes in reproductive effort and terminal investment in female Nile lechwe. J Mammal 90: 40-46

Borries C (1997) Infanticide in seasonally breeding multimale groups of Hanuman langurs (Presbytis entellus) in Ramnagar (South Nepal). Behav Ecol Sociobiol 41: $139-150$

Borries C, Sommer V, Srivastava A (1991) Dominance, age, and reproductive success in free-ranging female hanuman langurs (Presbytis entellus). Int J Primatol 3: 231-257

Borries C, Koening A (2000) Infanticide in hanuman langurs: social organisation, male migration, and weaning age. In van Schaik CP, Janson CH (eds) Infanticide by males and its implications. Cambridge, UK, Cambridge University Press, pp. 99122

Brown M (2013) Food and range defence in primates. Anim Behav 85: 807-816

Burrell AS, Jolly CJ, Tosi AJ, Disotell TR (2009) Mitochondrial evidence for the hybrid origin of the kipunji, Rungwecebus kipunji (Primates: Papionini). Mol Phylogenet 
Evol 51: 340-348

Butynski TM (1988) Guenon birth seasons and correlates with rainfall and food. In Gautier-Hion A, Bourlière F, Gautier JP, Kingdon J (eds) A primate radiation: evolutionary biology of the African guenons, Cambridge University Press, New York, pp 284-322

Chalmers NR, Rowell TE (1971) Behaviour and female reproductive cycles in a captive group of mangabeys. Folia Primatol 14:1-14

Chancellor RL, Isbell LA (2009a) Food site residence time and female competitive relationship in wild gray-cheeked mangabeys (Lophocebus albigena). Behav Ecol Sociobiol 63: 1447-1458

Chancellor RL, Isbell LA (2009b) Female grooming markets in a population of graycheeked mangabeys (Lophocebus albigena). Behav Ecol 20: 78-86

Chapman CA, Wrangham RW, Chapman LJ, Kennard DK, Zanne AE (1999) Fruit and flower phenology at two sites in Kibale National Park, Uganda. J Trop Ecol 15: $189-211$

Chapman CA, Chapman LJ, Struhsaker TT, Zanne AE, Connie J, Clark CJ, Poulsen JR (2005) A long-term evaluation of fruiting phenology: importance of climate change. J Trop Ecol 21: 1-14

Chapman CA, Chapman LJ, Jacob AL, Rothman JM, Omeja P, Reyna-Hurtado R, Hartter J, Lawes MJ (2010) Tropical tree community shifts: Implications for wildlife conservation. Biol Conserv 143: 366-374

Cheney DL, Seyfarth RM, Andelman, SJ, Lee PC (1988) Reproductive success in vervet monkeys. In Clutton-Brock TH (ed) Reproductive success, University of Chicago, Press, Chicago, pp 384-402 
Cheney DL, Seyfarth RM, Fischer J, Beehner J, Bergman T, Johnson SE, Kitchen DM, Palombit RA, Rendall D, Silk JB (2004) Factors affecting reproduction and mortality among baboons in the Okavango Delta, Botswana. Int J Primatol 25: 401428

Clutton-Brock TH (1984) Reproductive effort and terminal investment in iteroparous animals. Amer Nat 123: 212-229

Clutton-Brock TH, Albon SD, Guiness FE (1984) Maternal dominance, breeding success and birth sex ratios in red deer. Nature 308: 358-360

Cords M, Chowdhury S (2010) Life history of Cercopithecus mitis stuhlmanni in the Kakamega Forest, Kenya. Int J Primatol 31: 433-455

Cords M, Fuller JL (2010) Infanticide in Cercopithecus mitis stuhlmanni in the Kakamega Forest, Kenya: variation in the occurrence of an adaptive behavior. Int $\mathrm{J}$ Primatol 31: 409-431

Creel S, Creel NM (2002) The African wild dog: behavior, ecology and conservation. Princeton University Press, Princeton, New Jersey

Danjou MC (1972) Contribution a 1 Etude du Comportement Sexuel de Cercocebus albigena. Unpublished thesis, Universite de Rennes, France

Deputte BL (1991) Reproductive parameters of captive grey-cheeked mangabeys. Folia Primatol 57: 57-69

Descamps S, Boutin S, Berteaux D, Gaillard J (2008) Age-specific variation in survival, reproductive success and offspring quality in red squirrels: evidence of senescence. Oikos 117: 1406-1416

Di Fiore A, Rendall D (1994) Evolution of social organization: A reappraisal for primates by using phylogenetic methods. Proc Natl Acad Sci 91: 9941-9945. 
Dittus WPJ (1979) The evolution of behaviours regulating density and age-specific sex ratios in a primate population. Behaviour 69: 265-302

Dolhinow P, McKenna JJ, Vonder Haar Laws J (1979) Rank and reproduction among female langur monkeys: aging and improvement. Aggress Behav 5: 19-30

Drickamer LC (1974) A ten-year summary of reproductive data for free-ranging Macaca mulatta. Folia Primatol 21: 61-80

Dunbar RIM (1980) Demographic and life history variables of a population of gelada baboons (Theropithecus gelada). J Anim Ecol 49: 485-506

Emery Thompson M, Wrangham RW (2008) Diet and reproductive function in wild female chimpanzees (Pan troglodytes schweinfurthii) at Kibale National Park, Uganda. Am J Phys Anthropol 135: 171-181

Faraway JJ (2005) Extending the linear model with R: generalized linear, mixed effects and nonparametric regression models. CRC PressINC, pp. 61

Fedigan LM (2003) Impact of male takeovers on infant deaths, births and conceptions in Cebus capucinus at Santa Rosa, Costa Rica. Int J Primatol 24: 723-741

Fedigan LM, Fedigan L, Gouzoules S, Gouzoules H, Koyama N (1986) Lifetime reproductive success in female Japanese macaques. Folia Primatol 47: 143-157

Fernandez D, Doran-Sheehy D, Borries C, Brown JL (2014) Reproductive characteristics of wild Sanje mangabeys (Cercocebus sanjei). Am J Primatol. DOI: 10.1002/ajp.22301

Fruteau C, Range F, Noe R (2010) Infanticide risk and infant defence in multi-male freeranging sooty mangabeys, Cercocebus atys. Behav Process 83: 113-118

Fürtbauer I, Schülke O, Heistermann M, Ostner J (2010) Reproductive and life history parameters of wild female Macaca assamensis. Int J Primatol 31: 501-517 
Gagliardi C, Liukkonen JR., Phillippi-Falkenstein KM, Harrison RM, Kubisch HM (2007) Age as a determinant of reproductive success among captive female rhesus macaques (Macaca mulatta). Reprod 133: 819-826

Harcourt AH (1987) Dominance and fertility among female primates. J Zool (Lond) 213: $471-487$

Harris EE, Disotell TR (1998) Nuclear gene trees and the phylogenetic relationships of the mangabeys (Primates: Papionini). Mol Biol Evol 15: 892-900

Hawkes K, Smith KR (2010) Do women stop early? Similarities in fertility decline in humans and chimpanzees. Ann N Y Acad Sci 1204: 43-53

Henzi SP, Barrett L (2003) Evolutionary ecology, sexual conflict, and behavioral differentiation among baboon populations. Evol Anthropol 12: 217-230

Herndon JG, Paredes J, Wilson ME, Bloomsmith MA, Chennareddi L, Walker ML (2012) Menopause occurs late in life in the captive chimpanzee (Pan troglodytes). Age 34: 1145-1156

Hoffman CL, Higham JP, Mas-Rivera A, Ayala JE, Maestripieri D (2010) Terminal investment and senescence in rhesus macaques (Macaca mulatta) in Cayo Santiago. Behav Ecol 21: 972-978

Isbell LA (1991) Contest and scramble competition: patterns of female aggression and ranging behavior among primates. Behav Ecol 2: 143-155

Isbell LA, Young TP (2002) Ecological models of female social relationships in primates: similarities, disparities, and some directions for future clarity. Behaviour 139: 177202

Janmaat KRL, Byrne RW, Zuberbühler K (2006) Evidence for spatial memory of fruiting states of rain forest fruit in wild ranging mangabeys. Anim Behav 71: 797-807 
Janmaat RL, Chancellor RL (2010) Exploring new areas: how important is long-term spatial memory for mangabey (Lophocebus albigena johnstonii) foraging efficiency? Int J Primatol 31: 863-886

Johnson RL, Kapsalis E (1995) Ageing, infecundity and reproductive senescence in freeranging female rhesus monkeys. J Reprod Fertility 105: 271-278

Johnson RL, Kapsalis E (2008) Heterogeneity of reproductive aging in free-ranging female rhesus macaques. In Atsalis S, Margulis SW, Hof PR (eds). Primate Reproductive Aging: Cross-Taxon Perspectives, Basel, Karger, pp. 62-79

Jones OR, Scheuerlein A, Salguero-Gomez R, Camarda CG, Schaible R, Casper BB, Dahlgren JP, Ehrlen J, Garcia MB, Menges ES, Quintana-Ascencio PF, Caswell H, Baudisch A, Vaupel JW (2014) Diversity of ageing across the tree of life. Nature 505: 169

Koyama N, Norikosho K, Mano T (1975) Population dynamics of Japanese monkeys in Arashiyama. In Kondo S, Kawai M, Ehora MA (eds) Contemporary primatology, Karger, Basel, pp. 411-417

McCabe GM, Emery Thompson M (2013) Reproductive seasonality in wild Sanje mangabey (Cercocebus sanjei), Tanzania: relationship between the capital breeding strategy and infant survival. Behaviour 150: 1399-1429

McNaughton SJ (1985) Ecology of a grazing ecosystem: the Serengeti. Biol Monogr 55: 259-294

Olupot W (1998) Long-term variation in mangabey (Cercocebus albigena johnstonii Lydekker) feeding in Kibale National Park, Uganda. Afr J Ecol 36: 96-101

Olupot W, Waser PM (2001) Correlates of intergroup transfer in male grey-cheeked mangabeys. Int J Primatol 19: 169-187 
Olupot W, Waser PM (2013) Lophocebus albigena Grey-cheeked mangabey. In Butynski TM, Kingdon J, Kalina J (eds) Mammals of Africa, vol. 2. Bloomsbury Press, London, pp. 206-209

Paul A, Kuester J, Podzuweit D (1993) Reproductive senescence and terminal investment in female Barbary macaques (Macaca sylvanus) at Salem. Int J Primatol 14: 105124

Pavelka MSM, Fedigan LM (1999) Reproductive termination in female Japanese monkeys: A comparative life history perspective. Am J Phys Anthropol 109: 455464

Pavelka MSM, Fedigan LM (2012). Costs and benefits of old age reproduction in the Arashiyama West female Japanese macaques. In Leca JB, Huffman MA, Vasey P (eds.) The monkeys of stormy mountain: 60 years of primatological research on the Japanese macaques of Arashiyama, Cambridge University Press, pp 131-152

Perheentupa A, Huhtaniemi I (2009) Aging of the human ovary and testis. Mol Cell Endocrinol 299: 2-13

Pusey A, Williams J, Goodall J (1997) The influence of dominance rank on the reproductive success of female chimpanzees. Science 277: 828-831

R Development Core Team 2011. R: A language and environment for statistical computing. R Foundation for Statistical Computing, Vienna, Austria. ISBN 3900051-07-0, URL http://www.R-project.org/.

Roach D, Carey JR (2014) Population biology of aging. Ann Rev Ecol Evol Syst, 45

Robbins AM, Robbins MM, Gerald-Steklis N, Steklis HD (2006) Age-related patterns of reproductive success among female mountain gorillas. Am J Phys Anthropol 131: $511-521$

Robinson JG (1988) Group size in wedge-capped capuchin monkeys Cebus olivaceus and 
the reproductive success of males and females. Behav Ecol Sociobiol 23: 187197

Ron T, Henzi SP, Motro U (1996) Do female chacma baboons compete for a safe spatial position in a southern woodland habitat? Behaviour 133: 475-490

Rowell TE, Chalmers NR (1970) Reproductive cycles of the mangabey Cercocebus albigena. Folia Primatol 12: 264-272

Setchell JM, Phyllis LC, Wickings EJ, Dixson AF (2002) Reproductive parameters and maternal investment in mandrills (Mandrillus sphinx). Int J Primatol 23: 51-68

Sherry DS (2002) Reproductive seasonality in chimpanzees and humans: ultimate and proximate factors. Dissertation, Harvard University, Cambridge

Silk JB, Short J, Roberts J, Kusnitz J (1993) Gestation length in rhesus macaques (Macaca mulatta). Int J Primatol 14: 95-104

Struhsaker TT (1975) The red colobus monkey. University of Chicago Press, Chicago. Strum SC, Western JD (1982) Variation in fecundity with age and environment in olive baboons (Papio anubis). Am J Primatol 3: 61-76

Sugiyama Y, Ohsawa Y (1982) Population dynamics of Japanese monkeys with special reference to the effect of artificial feeding. Folia Primatol 39: 238-263

Tian JD, Wang ZL, Lu JQ, Wang BS, Chen JR (2013) Reproductive parameters of female Macaca mulatta tcheliensis in the temperate forest of Mount Taihangshan, Jiyuan, China. Am J Primatol 75: 605-612

Trivers RL (1972) Parental investment and sexual selection. In Campbell B (ed.) Sexual selection and the descent of man, 1871-1971, Aldine, Chicago, pp. 136-179 van Noordwijk MA, van Schaik CP (1987) Competition among female long-tailed macaques, Macaca fascicularis. Anim Behav 35: 577-589 
van Noordwijk MA, van Schaik CP (1999) The effect of dominance rank and group size on female lifetime reproductive success in wild long-tailed macaques, Macaca fascicularis. Primates 40: 105-130

van Schaik CP (1989). The ecology of social relationships amongst female primates. In Standen V, Foley RA (eds). Comparative socioecology: the behavioural ecology of humans and other mammals Blackwell, Oxford, pp. 195-218

Videan EN, Fritz J, Heward CB, Murphy J (2008) Reproductive aging in female chimpanzees (Pan troglodytes). Interdiscip Top Gerontol 36: 103-118

Walker SE, Strasser ME, Field LP (2004) Reproductive parameters and life-history variables in captive golden-bellied mangabeys (Cercocebus agilis chrysogaster). Am J Primatol 64:123-131

Wallis SJ (1983) Sexual behaviour and reproduction of Cercocebus albigena johnstoni in Kibale Forest, western Uganda. Int J Primatol 4: 153-166

Waser PM (1974) Intergroup interaction in a forest monkey: the mangabey Cercocebus albigena. Dissertation, The Rockefeller University, New York, USA

Waser PM (1975) Experimental playbacks show vocal mediation of intergroup avoidance in a forest monkey. Nature 255: 56-58

Waser PM (1977) Feeding, ranging and group size in the mangabey, Cercocebus albigena. In Clutton-Brock TH (ed) Primate ecology, Academic Press, London, pp $183-222$

Waser PM (1978) Post-reproductive survival and behavior in a free-ranging female mangabey. Folia Primatol 29: 142-160

Wasser S, Norton G, Rhine R, Klein N, Kleindorfer S (1998) Ageing and social rank effects on the reproductive system of free-ranging yellow baboons (Papio cynocephalus) at Mikumi National Park, Tanzania. Hum Reprod Update 4: 430-438 
Arlet et al. p. 37

Weladji RB, Mysterud A, Holand O, Lenvik D (2002) Age-related reproductive effort in reindeer (Rangifer tarandus): evidence of senescence. Oecologia 131: 79-82

Wrangham RW (1980) An ecological model of female-bonded primate groups.

Behaviour 75: 262-300 
Arlet et al. p. 38

\section{Figure legends}

Figure 1. Distribution of births per month in gray-cheeked mangabeys from 2004-2012 in Kibale National Park, Uganda.

Figure 2. Changes in cycle frequency and birth rate with age in high- vs. low-ranking female gray-cheeked mangabeys in Kibale National Park, Uganda for the years 20042012 (model result, see text). Gestation and lactation periods have been omitted and thus a year might correspond to a longer period in time. This figure is based on local polynomial regression fitting. Due to the small sample size of the data, the actual proportions are variable and as such are not useful for plotting. This figure is presented for illustrative purposes as the actual effects are analyzed using statistical models. HR = high-ranking females; LR = low-ranking females. 